\title{
FAKTOR-FAKTOR YANG MEMPENGARUHI SKEPTISISME PROFESIONAL AUDITOR PADA KANTOR AKUNTAN PUBLIK DI SUMATERA
}

\author{
Oleh : \\ Christina, SE, M.Si
}

Program Studi Akuntansi Fakultas Ekonomi Universitas Satya Negara Indonesia

\begin{abstract}
ABSTRAK
Penelitian ini bertujuan untuk mendapatkan bukti empiris mengenai faktor-faktor yang mempengaruhi skeptisisme professional auditor pada KAP di wilayah Sumatera, diantaranya : pengalaman, kesadaran etis, dan situasi audit. Populasi penelitian ini adalah seluruh auditor yang bekerja pada Kantor Akuntan Publik di wilayah Sumatera. Dalam penelitian ini teknik pengambilan sampel menggunakan kuesioner dengan skala likert 5 poin. Data yang diperoleh melalui penyebaran kuesioner dan berdasarkan kriteria yang telah ditetapkan terdapat 90 kuesioner yang dapat diolah. Data yang diperoleh dianalisis dengan regresi berganda (multiple regression) dengan menggunakan program SPSS.

Hasil penelitian ini menunjukkan bahwa pengalaman, kesadaran etis, dan situasi audit berpengaruh signifikan terhadap skeptisisme professional auditor pada Kantor Akuntan Publik di Sumatera. Artinya semakin lama pengalaman seorang auditor maka akan semakin tinggi skeptisisme professional oleh seorang auditor, semakin tinggi tingkat kesadaran etis yaitu tindakan yang diambil dalam pengambilan keputusan maka akan semakin meningkat skeptisisme professional auditor, semakin besar tingkat resiko penemuan yang direncanakan dalam menghadapi suatu situasi audit maka akan semakin meningkat skeptisisme professional auditor. Sehingga dalam pengumpulan bukti audit, auditor dituntut untuk memiliki skeptisisme yang tinggi. Dengan demikian, citra profesi auditor akan tetap terjaga.
\end{abstract}

Kata Kunci : Pengalaman, Kesadaran Etis, Situasi Audit, Skeptisisme Profesional Auditor. 


\section{PENDAHULUAN}

\section{Latar Belakang}

Profesi akuntan publik ini merupakan profesi kepercayaan masyarakat. Kepercayaan masyarakat terhadap mutu jasa yang diberikan oleh auditor akan menjadi lebih tinggi jika profesi tersebut menerapkan standar mutu tinggi terhadap pelaksanaan pekerjaan professional yang dilakukan oleh anggota profesinya. Dari profesi akuntan publik inilah masyarakat mengharapkan penilaian yang independen terhadap informasi yang disajikan oleh manajemen perusahaan dalam laporan keuangan.

Salah satu jasa dari akuntan publik adalah melakukan pemeriksaan atas laporan keuangan (SPAP, 2001). Pihak-pihak yang berkepentingan atas laporan keuangan yang telah diaudit diantaranya pimpinan perusahaan, pemegang saham, pemerintah, kreditur, dan karyawan. Laporan keuangan tersebut akan dipakai sebagai pedoman dalam pengambilan keputusan, oleh karena itu pemeriksaan atas laporan keuangan hendaklah dilakukan dengan sebaik-baiknya sesuai dengan standar yang telah ditetapkan agar tidak menyesatkan para pemakainya. Dalam melaksanakan tugasnya, auditor dituntut agar tidak menyimpang dari standar yang telah ditetapkan, menjunjung tinggi kaidah moral agar kualitas audit dan citra profesi akuntan publik tetap terjaga.

Seorang auditor dituntut untuk sangat berhati-hati dalam memberikan opininya. Kemampuan auditor dalam memberikan opini dengan didukung bukti yang cukup dan kompeten, sedikit banyaknya dipengaruhi oleh pengalaman yang dimiliki auditor tersebut. Semakin banyak pengalaman yang dimiliki oleh auditor, semakin banyak auditor berhadapan dengan kasus/temuan, sehingga opini yang diberikan akan lebih kompeten. Dengan adanya pengalaman terdahulu, maka auditor akan lebih berhati-hati dalam memberikan opini. Auditor yang cukup berpengalaman kinerjanya akan lebih baik bila dibandingkan dengan auditor yang masih sedikit pengalamannya (Yurniwati, 2004). Selanjutnya dalam standar umum dari standar auditing tersebut dijelaskan bahwa seseorang yang berprofesi dalam bidang auditing perlu memiliki pengalaman yang memadai dalam bidang auditing (SA seksi 210).

Pelaksanaan pekerjaan profesional juga tidak terlepas dari etika karena prilaku profesional diperlukan bagi semua profesi yang telah menjadi pilihannya untuk mendapat kepercayaan dari masyarakat. Pembuatan keputusan etis perlu dilakukan untuk merespon krisis etika dengan mengambil dan memperbaharui peraturan etika dengan menyediakan aturan-aturan dan prinsip-prinsip untuk menjaga anggotanya melalui prinsip kehati-hatian. Hal ini penting, karena profesi dalam bidang auditing memiliki reputasi yang disenangi jika dapat memelihara standar etis yang tinggi.

Situasi audit juga memberikan pengaruh pada auditor dalam pelaksanaan skeptisisme professionalnya. Dalam pelaksanaan pemeriksaan auditor dihadapkan pada situasi irregularities yang mengandung resiko seperti adanya hubungan istimewa, motivasi manajemen, klien yang tidak kooperatif, klien baru pertama kali audit dan klien bermasalah.

Auditor dituntut untuk melaksanakan skeptisisme professionalnya sehingga auditor dapat menggunakan kemahiran profesionalnya dengan cermat dan seksama, karena kemahiran professional seorang auditor mempengaruhi ketepatan pemberian opini yang 
diberikannya. Skeptisisme berasal dari kata skeptis yang berarti kurang percaya atau raguragu. Didalam SPAP (Standar Profesional Akuntan Publik, 2001) menyatakan skeptisisme professional auditor sebagai suatu sikap yang mencakup pikiran selalu mempertanyakan dan melakukan evaluasi secara kritis terhadap bukti audit. Dalam pengumpulan bukti, auditor harus senantiasa menggunakan skeptisisme professionalnya. Auditor diharapkan dapat lebih mendemonstrasikan tingkat tertinggi dari skeptisisme profesionalnya.

Skeptisisme professional ini perlu dimiliki oleh auditor agar hasil pemeriksaan atas laporan keuangan dapat dipercaya. Sebagaimana diketahui profesi akuntan publik merupakan profesi yang salah satu tugasnya menyediakan jasa pemeriksaan laporan keuangan (SPAP, 2001). Dalam melakukan pemeriksaan seorang auditor harus senantiasa berpedoman pada Standar Profesional Akuntan Publik.

Shaub dan Lawrence (1996) mengartikan skeptisisme professional auditor sebagai berikut "professional skepticism is a choice to fulfill the professional auditor's duty to prevent or reduce or harmful consequences of another person's behaviour". Dari definisi ini dapat diartikan bahwa skeptisisme professional auditor adalah adanya suatu sikap yang kritis terhadap bukti audit dalam bentuk keraguan, pertanyaan atau ketidaksetujuan dengan pernyataan klien atau kesimpulan yang dapat diterima umum. Skeptisisme professional digabungkan kedalam literatur professional yang membutuhkan auditor untuk mengevaluasi kemungkinan kecurangan material (Loebbeck, et al, 1984) dalam Maghfirah (2008). Selain itu juga sebagai pilihan untuk memenuhi tugas audit profesionalnya untuk mencegah dan mengurangi konsekuensi bahaya dan perilaku orang lain (SPAP, 2001).

Berdasarkan uraian tersebut, maka peneliti tertarik untuk melakukan penelitian dengan judul :"faktor-faktor yang mempengaruhi skeptisisme profesional auditor pada kantor akuntan publik di sumatera".

\section{Perumusan Masalah}

Apakah pengalaman, kesadaran etis, dan situasi audit berpengaruh terhadap skeptisisme profesional auditor?

\section{Tujuan penelitian}

Untuk mengetahui pengaruh pengalaman, kesadaran etis, dan situasi audit berpengaruh terhadap skeptisisme profesional auditor.

\section{ManfaatPenelitian}

1. Bagi akademisi, menjadi bahan literatur untuk pengembangan penelitian selanjutnya tentang perilaku akuntan publik.

2. Bagi peneliti, dapat memberikan kontribusi keilmuan dan mengembangkan wawasan mengenai perilaku akuntan publik di Wilayah Sumatera.

3. Memberi masukan bagi peneliti selanjutnya untuk dapat melakukan penelitian lebih lanjut di masa yang akan datang dan sebagai tambahan literatur di bidang ilmu pengetahuan. 


\section{LANDASAN TEORI}

\section{Pengalaman Auditor}

Standar umum pertama dari standar auditing menyatakan bahwa Audit harus dilaksanakan oleh seseorang atau lebih yang memiliki keahlian dan pelatihan teknis yang cukup sebagai auditor (SA Seksi 210).

Pengalaman dalam bidang auditing diperlukan sebagai kemampuan seseorang untuk melakukan supervisi dan review terhadap hasil pekerjaan dari asisten junior yang baru memasuki karier auditing sebagai suatu sarana untuk mencapai derajat keahlian dalam pelaksanaan auditing. Pernyataan ini didasarkan pada standar umum pertama dari standar auditing yang menyatakan bahwa Asisten junior yang baru masuk ke dalam karier auditing harus memperoleh pengalaman profesionalnya dengan mendapatkan supervisi memadai dan review atas pekerjaannya dari atasan yang lebih berpengalaman (SA Seksi 210).

Dari pernyataan tersebut dapat diartikan bahwa dalam melaksanakan audit, auditor harus memiliki keahlian tentang audit dan pelatihan teknis audit dalam melaksanakan audit dengan tujuan agar dalam pemberian opini auditor tidak merasa canggung atau ragu. Hal ini didasarkan pada paragraf selanjutnya dari standar umum pertama dari standar auditing yang menyatakan seorang auditor harus bertindak sebagai ahli dalam bidang akuntansi dan bidang auditing, dimana pencapaian keahlian tersebut dimulai dari pendidikan formal dan pelatihan teknis yang diperluas melalui pengalaman-pengalaman selanjutnya dalam pelaksanaan audit (SA Seksi 210).

Di Indonesia, parameter pengalaman yang digunakan dalam profesi auditing ditetapkan sekurang-kurangnya tiga tahun, dimana ketetapan tersebut ditetapkan melalui SK Menteri Keuangan RI No. 43/KMK.017/1997, tanggal 27 januari 1997 tentang jasa akuntan publik. Dalam surat keputusan tersebut, izin menjalankan praktik sebagai akuntan publik diberikan oleh menteri keuangan jika seseorang memenuhi persyaratan sebagai berikut:

1) Berdomisili di wilayah Indonesia.

2) Lulus ujian sertifikasi akuntan publik yang diselenggarakan oleh Ikatan Akuntan Indonesia (IAI).

3) Menjadi anggota Ikatan Akuntan Indonesia (IAI).

4) Telah memiliki pengalaman kerja sekurang-kurangnya tiga tahun sebagai akuntan dengan reputasi baik di bidang auditing.

\section{Kesadaran Etis}

Kesadaran etis terdiri dari kata Kesadaran dan Etis. Kesadaran merupakan suatu keadaan tahu, mengerti dan merasa. Sebagaimana dikatakan oleh Walters dalam Agoes (2009), kesadaran dalam keadaannya yang murni yang bersifat mutlak, lebih mutlak dari kecepatan cahaya yang melambat ketika memasuki medium fisik seperti atmosfer bumi, serta lebih mutlak dari keberadaan benda.

Dari definisi-definisi tersebut, maka kesadaran etis dapat didefinisikan sebagai berikut Kesadaran etis adalah totalitas dari pengalaman dan kehidupan mental seseorang dalam melakukan tindakan yang disesuaikan dengan etika, sebagai konsekuensi dari keberadaan dirinya terhadap lingkungan disekelilingnya. Agoes (2009) memberikan definisi etika sebagai berikut: Etika pada intinya mempelajari perilaku/tindakan seseorang dan kelompok atau 
lembaga yang dianggap baik atau tidak baik. Ukuran untuk menilai baik atau tidaknya suatu tindakan bila dilihat dari hakikat manusia utuh adalah dilihat dari manfaat atau kerugiannya bagi orang lain; kemampuan tindakan tersebut dalam menciptakan kebahagian individu ; dan kemampuan tindakan tersebut dalam meningkatkan keimanan/kesadaran spiritual seseorang.

\section{Situasi Audit}

Dalam audit yang dilakukannya, auditor biasanya dihadapkan pada situasi audit yang secara umum dibagi atas 2 macam, yaitu situasi audit yang memiliki resiko rendah (situasi regularities) dan situasi yang memiliki resiko tinggi (situasi irregularities) (Maghfirah, 2008).

Dalam situasi tertentu, risiko terjadinya kesalahan dan penyajian yang salah dalam akun dan dalam laporan keuangan jauh lebih besar dibandingkan dengan situasi yang biasa. Irregularities sering diartikan sebagai suatu situasi dimana terdapat ketidakberesan atau kecurangan yang dilakukan dengan sengaja. Situasi audit yang beresiko tinggi ini menuntut auditor untuk memiliki kewaspadaan yang tinggi terhadap kecurangan yang mungkin terjadi agar audit yang dilakukannya efektif. Kecurangan sering menyangkut hal-hal berikut ini: (a) suatu tekanan atau dorongan untuk melakukan kecurangan, (b) suatu peluang yang dirasakan ada untuk melaksanakan kecurangan.

\section{Skeptisisme Profesional Auditor}

Seseorang yang berprofesi dibidang auditing diharuskan untuk selalu bersikap professional dalam melaksanakan tugasnya dengan cermat dan seksama. Pernyataan ini didasarkan pada standar umum ketiga dari standar auditing yang menyatakan bahwa Dalam pelaksanaan dan penyusunan laporannya, auditor wajib menggunakan kemahiran professionalnya dengan cermat dan seksama (SA seksi 230).

Oleh karena itu, selanjutnya penggunaan kemahiran professional dengan cermat dan seksama menurut auditor untuk melaksanakan skeptisisme professional. Pernyataan ini juga didasarkan pada standar umum ketiga dari auditing, yang menyatakan bahwa Penggunaan kemahiran professional dengan cermat dan seksama menuntut auditor untuk melaksanakan skeptisisme professional (SA Seksi 230).

Skeptisisme professional auditor diperlukan terutama untuk menjaga citra profesi akuntan publik. Oleh karena itu, dalam hal pengumpulan dan penilaian bukti audit secara objektif menuntut auditor untuk mempertimbangkan kompetensi dan kecukupan bukti tersebut. Selanjutnya, kompetensi dan kecukupan bukti audit tersebut dinilai dalam proses audit dengan menggunakan skeptisisme professional saat proses tersebut berlangsung. Sebab, skeptisisme professional adalah keraguan auditor terhadap pernyataan dan informasi klien, baik secara lisan maupun tulisan merupakan bagian dari proses audit (SA Seksi 230).

Skeptisisme bukanlah sikap sinis, tetapi merupakan sikap yang mengharapkan untuk mempertanyakan, meragukan atau tidak setuju dengan penyajian klien. Tetapi hal ini bukan berarti auditor harus menanamkan asumsi bahwa manajemen tidak jujur dan juga menganggap bahwa kejujuran manajemen tidak perlu dipertanyakan lagi. Oleh karena itu, auditor tidak harus puas dengan bukti yang diberikan manajemen. Sebab, skeptisisme professional adalah sikap yang mencakup pikiran yang selalu mempertanyakan dan melakukan evaluasi secara kritis terhadap bukti audit (SA Seksi 230). 


\section{Model Penelitian}

\begin{tabular}{|l|c|}
\hline Pengalaman $\left(\mathrm{X}_{1}\right)$ \\
\hline Kesadaran Etis $\left(\mathrm{X}_{2}\right)$ \\
\hline Situasi Audit $\left(\mathrm{X}_{3}\right)$
\end{tabular}

METODE PENELITIAN

\section{Jenis Penelitian}

Jenis data penelitian ini adalah data subjek (self report data). Data subjek berarti jenis data penelitian berupa opini, sikap, pengalaman, atau karakteristik seseorang atau sekelompok orang yang menjadi subjek penelitian atau responden. Sumber penelitian adalah data primer yaitu data yang diperoleh dengan survei lapangan yang menggunakan semua metode pengumpulan data original.

\section{Populasi dan Sampel Penelitian}

Populasi penelitian ini adalah seluruh auditor yang bekerja pada Kantor Akuntan Publik (KAP) dan terdaftar pada Institut Akuntan Publik Indonesia (IAPI) di wilayah Sumatera. Total populasi penelitian ini adalah 165 auditor.

Sampel dan Tingkat Pengembalian Kuesioner

\begin{tabular}{|l|c|}
\hline \multicolumn{1}{|c|}{ KETERANGAN } & TOTAL \\
\hline Kuesioner yang dikirim & 165 \\
\hline Kuesioner yang tidak mendapat respon & 69 \\
\hline Kuesioner yang kembali & 96 \\
\hline Kuesioner yang tidak dapat diolah & 6 \\
\hline Kuesioner yang dapat diolah & 90 \\
\hline Persentase Pengembalian Kuesioner (90/165x100\%) & $\mathbf{5 4 . 5 4 \%}$ \\
\hline
\end{tabular}

\section{Metode Analisis Data}

\section{a) Unit Analisa}

Unit analisa dalam penelitian ini adalah individu-individu auditor yang bekerja di KAP-KAP yang menjadi sampel.

b) Analisa Data

Data yang terkumpul yang dianalisa dengan menggunakan regresi berganda (multiple regression) guna mengetahui pengaruh variabel-variabel independen terhadap dependen dengan bantuan SPSS. Kemudian dilakukan pengecekan dengan menggunakan plot data linier atau tidak linear. 


\section{Model Regresi Yang Digunakan}

Dalam penelitian ini digunakan suatu model analisis regresi berganda, yaitu menggunakan variabel pengalaman, kesadaran etis, situasi audit dalam menjelaskan variabel skeptisisme professional auditor, sehingga didapat persamaan :

$$
\mathbf{Y}=\mathbf{a}+\mathbf{b}_{1} \mathbf{X}_{1}+\mathbf{b}_{2} \mathbf{X}_{2}+\mathbf{b}_{3} \mathbf{X}_{3}+e
$$

Hasil analisis regresi berganda dengan metode enter untuk model analisis dapat dilihat pada Tabel berikut :

Hasil Analisis Regresi dengan Metode Enter

Coefficients $^{a}$

\begin{tabular}{|c|c|c|c|c|c|c|c|c|}
\hline \multirow{2}{*}{\multicolumn{2}{|c|}{ Model }} & \multicolumn{2}{|c|}{$\begin{array}{l}\text { Unstandardized } \\
\text { Coefficients }\end{array}$} & \multirow{2}{*}{$\begin{array}{c}\begin{array}{c}\text { Standardized } \\
\text { Coefficients }\end{array} \\
\text { Beta }\end{array}$} & \multirow[b]{2}{*}{$t$} & \multirow[b]{2}{*}{ Sig. } & \multicolumn{2}{|c|}{ Collinearity Statistics } \\
\hline & & B & $\begin{array}{l}\text { Std. } \\
\text { Error }\end{array}$ & & & & Tolerance & VIF \\
\hline \multirow[t]{4}{*}{1} & (Constant) & -9.651 & 6.276 & & -1.538 & .128 & & \\
\hline & Pengalaman & .891 & .393 & .199 & 2.270 & .026 & .404 & 2.472 \\
\hline & Kesadaran Etis & .366 & .139 & .237 & 2.636 & .010 & .383 & 2.609 \\
\hline & Situasi Audit & 1.554 & .247 & .450 & 6.281 & .000 & .604 & 1.657 \\
\hline
\end{tabular}

berikut :

Dari tabel tersebut hasil persamaan regresi dapat ditentukan sebagai

$$
Y=-9.651+0.891 X_{1}+0.366 X_{2}+1.554 X_{3}+e
$$

Keterangan :

$\mathrm{Y} \quad=$ Skeptisisme Profesional Auditor

$\mathrm{X}_{1} \quad=$ Pengalaman

$\mathrm{X}_{2} \quad=$ Kesadaran Etis

$\mathrm{X}_{3} \quad=$ Situasi Audit

a $\quad=$ Konstanta

$e \quad=$ Galat (eror terms) 


\section{ANALISA DAN HASIL PEMBAHASAN}

\section{Hasil Pengujian Hipotesis}

Analisis data dilakukan terhadap 90 jawaban responden yang memenuhi kriteria untuk dilakukan pengolahan data.

Descriptive Statistics

\begin{tabular}{|l|r|r|r|}
\hline & Mean & Std. Deviation & $\mathrm{N}$ \\
\hline Skeptisisme Profesional Auditor & 51.7556 & 11.96090 & 90 \\
Pengalaman & 7.9444 & 2.66632 & 90 \\
Kesadaran Etis & 20.4444 & 7.73597 & 90 \\
Situasi Audit & 18.9111 & 3.46295 & 90 \\
\hline
\end{tabular}

Dari tabel dapat dilihat, bahwa rata-rata jawaban responden untuk variabel Skeptisisme professional auditor adalah 51.75, diperoleh standar deviasi 11.96. Pengalaman auditor dengan nilai rata-rata jawaban responden 7.94 diperoleh standar deviasi 2.66. Kesadaran Etis dengan nilai rata-rata jawaban responden 20.44 diperoleh standar deviasi 7.73. Situasi Audit dengan nilai rata-rata jawaban responden 18.91 diperoleh standar deviasi 3.46.

\section{Analisis Uji Kualitas Data}

Setelah data dikumpulkan, diseleksi kelengkapannya untuk dianalisis. Langkah selanjutnya adalah melakukan pengujian terhadap validitas dan realibilitas data. Pengujian validitas dan reliabilitas dilakukan secara keseluruhan terhadap seluruh item pertanyaan yang digunakan untuk mengukur variabelvariabel penelitian.

\section{Uji Validitas Data}

Berdasarkan uji validitas butir-butir pertanyaan dalam kuesioner penelitian ini dengan menggunakan Korelasi Pearson melalui aplikasi SPSS, setiap butir pertanyaan berkorelasi positif terhadap skor total dengan signifikansi pada level 0.05. Untuk mengetahui validitas setiap butir pertanyaan pada kuesioner, maka

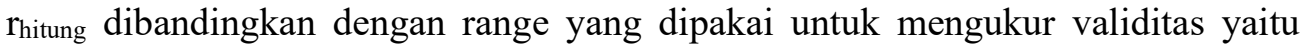
berada disekitar angka $-1,0$ dan +1 . Jika $\mathrm{r}_{\text {hitung }}$ semakin mendekati angka 1 , maka item pertanyaan tersebut valid, dan sebaliknya jika $r_{\text {hitung }}$ mendekati angka 0 (semakin menjauhi angka 1) maka item pertanyaan tersebut tidak valid digunakan dalam sebuah penelitian.

Instrumen variabel pertama, pengalaman auditor terdiri dari tiga pertanyaan. Dari hasil perhitungan korelasi setiap butir pertanyaan terhadap totalnya, diperoleh hasil berkisar antara $0.255-0.695$. Hasil perhitungan korelasi setiap butir pertanyaan tersebut mendekati angka +1 , sehingga dapat disimpulkan 
bahwa setiap butir pertanyaan pada instrumen pengalaman auditor adalah valid dan setiap butir pertanyaan memiliki korelasi positif dengan skor totalnya dengan signifikansi 0.05 . Hasil perhitungan tersebut dapat dilihat pada Tabel berikut:

\section{Rangkuman Validitas Instrumen Pengalaman Auditor}

Item-Total Statistics

\begin{tabular}{|l|r|r|r|r|}
\hline & $\begin{array}{c}\text { Scale Mean if } \\
\text { Item Deleted }\end{array}$ & $\begin{array}{c}\text { Scale Variance if } \\
\text { Item Deleted }\end{array}$ & $\begin{array}{c}\text { Corrected Item- } \\
\text { Total Correlation }\end{array}$ & $\begin{array}{c}\text { Cronbach's Alpha } \\
\text { if Item Deleted }\end{array}$ \\
\hline X1.1 & 5.8778 & 2.828 & .578 & .456 \\
X1.2 & 5.6111 & 2.914 & .695 & .273 \\
X1.3 & 4.4000 & 5.276 & .255 & .818 \\
\hline
\end{tabular}

Instrumen variabel kedua, kesadaran etis terdiri dari 9 pertanyaan. Dari hasil perhitungan korelasi setiap butir pertanyaan terhadap totalnya, diperoleh hasil berkisar antara $0.346-0.840$. Hasil perhitungan korelasi setiap butir pertanyaan tersebut mendekati angka +1 , sehingga dapat disimpulkan bahwa setiap butir pertanyaan pada instrumen kesadaran etis adalah valid dan setiap butir pertanyaan memiliki korelasi positif dengan skor totalnya dengan tingkat signifikansi 0.05 . Hasil perhitungan tersebut dapat dilihat pada Tabel berikut :

\section{Rangkuman Validitas Instrumen Kesadaran Etis} Item-Total Statistics

\begin{tabular}{|l|r|r|r|r|}
\hline & $\begin{array}{c}\text { Scale Mean if } \\
\text { Item Deleted }\end{array}$ & $\begin{array}{c}\text { Scale Variance if } \\
\text { Item Deleted }\end{array}$ & $\begin{array}{c}\text { Corrected Item- } \\
\text { Total Correlation }\end{array}$ & $\begin{array}{c}\text { Cronbach's Alpha } \\
\text { if Item Deleted }\end{array}$ \\
\hline X2.1 & 17.9444 & 53.132 & .346 & .900 \\
X2.2 & 18.0222 & 53.685 & .353 & .899 \\
X2.3 & 17.7222 & 46.832 & .762 & .873 \\
X2.4 & 18.0000 & 46.449 & .691 & .877 \\
X2.5 & 17.9333 & 42.355 & .803 & .867 \\
X2.6 & 17.8667 & 41.420 & .840 & .863 \\
X2.7 & 18.2667 & 50.198 & .538 & .889 \\
X2.8 & 18.1222 & 43.974 & .756 & .871 \\
X2.9 & 18.0778 & 45.511 & .715 & .875 \\
\hline
\end{tabular}

Instrumen variabel ketiga, situasi audit terdiri dari 5 pertanyaan. Dari hasil perhitungan korelasi setiap butir pertanyaan terhadap totalnya., diperoleh hasil berkisar antara $0.380-0.747$. Hasil perhitungan korelasi setiap butir pertanyaan tersebut mendekati angka +1 , sehingga dapat disimpulkan bahwa setiap butir pertanyaan pada instrumen situasi audit adalah valid dan setiap butir pertanyaan memiliki korelasi positif dengan skor totalnya dengan tingkat signifikansi 0.05. Hasil perhitungan tersebut dapat dilihat pada Tabel berikut : 
Rangkuman Validitas Instrumen Situasi Audit Item-Total Statistics

\begin{tabular}{|l|r|r|r|r|}
\hline & $\begin{array}{c}\text { Scale Mean if } \\
\text { Item Deleted }\end{array}$ & $\begin{array}{c}\text { Scale Variance if } \\
\text { Item Deleted }\end{array}$ & $\begin{array}{c}\text { Corrected Item- } \\
\text { Total Correlation }\end{array}$ & $\begin{array}{c}\text { Cronbach's Alpha } \\
\text { if Item Deleted }\end{array}$ \\
\hline X3.1 & 15.4889 & 8.522 & .475 & .776 \\
X3.2 & 14.6333 & 9.403 & .380 & .800 \\
X3.3 & 15.2000 & 7.825 & .613 & .731 \\
X3.4 & 14.9333 & 7.389 & .747 & .687 \\
X3.5 & 15.3889 & 7.274 & .626 & .727 \\
\hline
\end{tabular}

Hasil perhitungan korelasi setiap butir pertanyaan instrumen skeptisisme professional auditor totalnya berkisar antara 0.265 - 0.877 . Hasil perhitungan korelasi setiap butir pertanyaan tersebut mendekati angka +1 . Dengan demikian dapat disimpulkan bahwa setiap butir pertanyaan pada instrumen skeptisisme professional auditor adalah valid dan setiap butir pertanyaan memiliki korelasi yang positif dengan skor totalnya dengan signifikansi 0.05 . Hal ini dapat dilihat pada tabel berikut:

Rangkuman Validitas Instrumen Skeptisisme Profesional Auditor Item-Total Statistics

\begin{tabular}{|l|r|r|r|r|}
\hline & $\begin{array}{c}\text { Scale Mean if } \\
\text { Item Deleted }\end{array}$ & $\begin{array}{c}\text { Scale Variance if } \\
\text { Item Deleted }\end{array}$ & $\begin{array}{r}\text { Corrected Item- } \\
\text { Total Correlation }\end{array}$ & $\begin{array}{r}\text { Cronbach's Alpha } \\
\text { if Item Deleted }\end{array}$ \\
\hline Y.1 & 48.2778 & 136.338 & .377 & .934 \\
Y.2 & 48.5222 & 122.342 & .800 & .923 \\
Y.3 & 48.4111 & 122.874 & .810 & .923 \\
Y.4 & 48.1111 & 149.044 & .265 & .951 \\
Y.5 & 48.3444 & 118.138 & .794 & .923 \\
Y.6 & 48.3222 & 117.951 & .789 & .924 \\
Y.7 & 48.1889 & 126.919 & .629 & .928 \\
Y.8 & 48.3222 & 121.277 & .822 & .923 \\
Y.9 & 48.2889 & 121.556 & .809 & .923 \\
Y.10 & 47.8778 & 130.311 & .623 & .929 \\
Y.11 & 48.2000 & 127.196 & .804 & .925 \\
Y.12 & 48.3889 & 119.184 & .877 & .921 \\
Y.13 & 48.2778 & 130.046 & .485 & .932 \\
Y.14 & 48.5444 & 117.509 & .845 & .922 \\
Y.15 & 48.5000 & 117.781 & .867 & .921 \\
& & & & \\
\hline
\end{tabular}

\section{Uji Reliabilitas Data}

Pengujian reliabilitas penelitian ini menggunakan koefisien Cronbach Alpha dengan taksiran batasan minimal 0.5. Variabel penelitian akan dikatakan reliabel jika Cronbach Alpha-nya memiliki nilai lebih besar dari 0.6. Sebaliknya jika koefisien alpha instrumen lebih rendah dari 0.6 maka instrument tersebut tidak reliabel untuk digunakan dalam penelitian. Pada Tabel berikut ini akan 
menerangkan hasil pengujian reliabilitas dari instrumen untuk setiap variabel penelitian.

\section{Rangkuman Reliabilitas Instrumen Pengalaman}

Reliability Statistics

\begin{tabular}{|l|l|}
\hline Cronbach's Alpha & $\mathrm{N}$ of Items \\
\hline
\end{tabular}

\begin{tabular}{r|r}
.675 & 3 \\
\hline
\end{tabular}

\section{Rangkuman Reliabilitas Instrumen Kesadaran Etis}

Reliability Statistics

\begin{tabular}{|l|l|}
\hline Cronbach's Alpha & $\mathrm{N}$ of Items \\
\hline
\end{tabular}

.892

\section{Rangkuman Reliabilitas Instrumen Situasi Audit}

Reliability Statistics

\begin{tabular}{|l|l|}
\hline Cronbach's Alpha & $\mathrm{N}$ of Items \\
\hline
\end{tabular}

.787

\section{Rangkuman Reliabilitas Instrumen Skeptisisme Profesional Auditor}

Reliability Statistics

\begin{tabular}{|r|r|}
\hline Cronbach's Alpha & N of Items \\
\hline .932 & 15 \\
\hline
\end{tabular}

Berdasarkan tabel dapat dilihat bahwa koefisien reliabilitas instrumen pengalaman menunjukkan Cronbach Alpha 0.675. Reliabilitas instrumen kesadaran etis menunjukkan Cronbach Alpha 0.892. Reliabilitas instrumen situasi audit menunjukkan Cronbach Alpha 0.787. Sedangkan untuk instrumen skeptisisme professional auditor menunjukkan Cronbach Alpha 0.932. Dari keempat aspek tersebut terlihat bahwa semua Cronbach Alpha lebih besar dari 0.6, sehingga dapat disimpulkan bahwa semua instrumen penelitian ini adalah reliabel.

\section{Uji Normalitas Data}

Untuk melihat normalitas rata-rata jawaban responden yang menjadi data dalam penelitian ini dapat dilihat dari normal probability plot. Jika data menyebar disekitar garis diagonal dan mengikuti arah garis diagonal, maka model regresi memenuhi asumsi normalitas. 


\section{Gambar Normal Probability Standardized Residual}

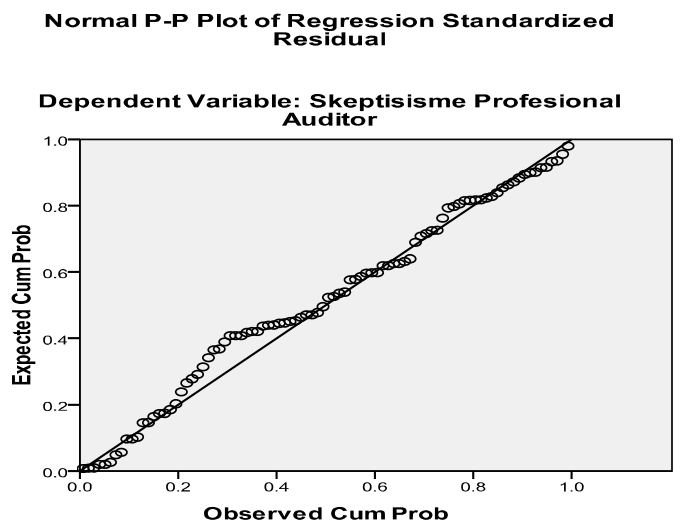

Dari grafik di atas dapat dilihat bahwa data tersebar disekitar garis lurus tersebut (tidak terpencar jauh dari garis lurus). Maka dapat disimpulkan bahwa persyaratan normalitas data adalah terpenuhi.

\section{Analisis Uji Asumsi Klasik}

\section{Multikolinearitas}

Tujuan dari uji multikolinearitas adalah untuk menguji apakah regresi ditemukan adanya korelasi antar variabel independen. Regresi yang bebas multikolinearitas ditandai dengan nilai Variance Inflation Factor (VIF) dan nilai Tolerance berkisar angka 5. Artinya bila toleransi kecil menunjukkan VIF yang besar. Untuk itu bila VIF $>5$ maka dianggap terjadi multikolinearitas dengan variabel lainnya, sebaliknya jika diperoleh VIF $<5$ maka dianggap tidak terjadi multikolinearitas antara satu variabel independen dengan variabel independen lainnya dalam persamaan regresi.

Nilai Tolerance dan VIF

Coefficients $^{a}$

\begin{tabular}{|c|c|c|c|c|c|c|c|c|}
\hline \multirow{2}{*}{\multicolumn{2}{|c|}{ Model }} & \multicolumn{2}{|c|}{$\begin{array}{l}\text { Unstandardized } \\
\text { Coefficients }\end{array}$} & \multirow{2}{*}{$\begin{array}{c}\begin{array}{c}\text { Standardized } \\
\text { Coefficients }\end{array} \\
\text { Beta }\end{array}$} & \multirow[b]{2}{*}{$\mathrm{t}$} & \multirow[b]{2}{*}{ Sig. } & \multicolumn{2}{|c|}{$\begin{array}{l}\text { Collinearity } \\
\text { Statistics }\end{array}$} \\
\hline & & B & $\begin{array}{l}\text { Std. } \\
\text { Error }\end{array}$ & & & & Tolerance & VIF \\
\hline \multirow[t]{4}{*}{1} & (Constant) & -9.651 & 6.276 & & -1.538 & .128 & & \\
\hline & Pengalaman & .891 & .393 & .199 & 2.270 & .026 & .404 & 2.472 \\
\hline & Kesadaran Etis & .366 & .139 & .237 & 2.636 & .010 & .383 & 2.609 \\
\hline & Situasi Audit & 1.554 & .247 & .450 & 6.281 & .000 & .604 & 1.657 \\
\hline
\end{tabular}

Pada tabel diatas nilai Tolerance dan nilai VIF untuk variabel independen berkisar angka 5, VIF untuk setiap variabel independen $<5$. Dengan demikian 
dapat disimpulkan bahwa variabel independen tidak mengalami ganguan multikolinearitas.

\section{Uji Heterokedastisitas}

Uji ini bertujuan untuk menguji apakah dalam sebuah model regresi linier terjadi ketidaksamaan varians dari residual pengamatan ke pengamatan yang lain. Jika diagram pencar yang ada membentuk pola-pola tertentu yang teratur maka regresi mengalami gangguan heterokedastisitas.Gambar dibawah ini merupakan gambar hasil uji heterokedastisitas dimana diagram pencar yang ada tidak membentuk pola atau acak, maka penelitian ini tidak mengalami gangguan heterokedastisitas.

\section{Gambar Scatterplot}

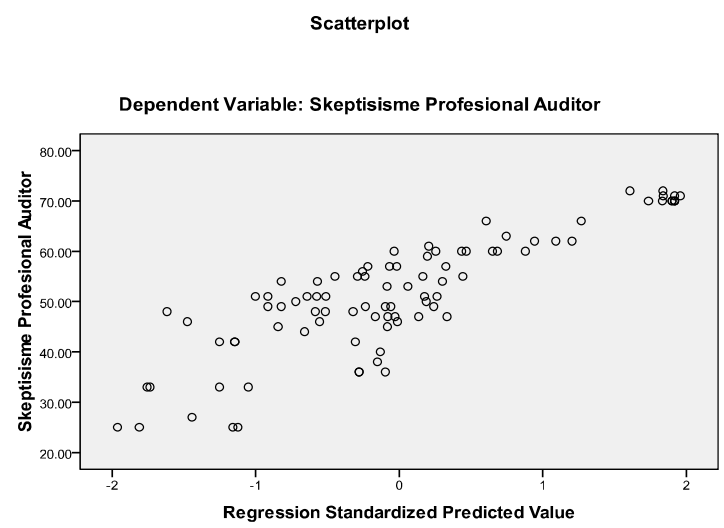

\section{Uji Autokorelasi}

Uji ini bertujuan untuk menguji apakah dalam sebuah regresi linear ada korelasi antara kesalahan pengganggu (error) pada periode $t$ dengan kesalahan pengganggu pada periode sebelumnya. Autokorelasi pada penelitian ini dideteksi dengan nilai Durbin-Watson (DW) melalui aplikasi SPSS.

Tabel Hasil Uji Autokorelasi Model Summary

\begin{tabular}{|c|c|c|c|c|c|c|c|c|c|c|}
\hline \multirow[b]{2}{*}{ Model } & \multirow[b]{2}{*}{$\mathrm{R}$} & \multirow[b]{2}{*}{$\begin{array}{c}\mathrm{R} \\
\text { Square }\end{array}$} & \multirow[b]{2}{*}{$\begin{array}{c}\text { Adjusted R } \\
\text { Square }\end{array}$} & \multirow[b]{2}{*}{$\begin{array}{l}\text { Std. Error of } \\
\text { the Estimate }\end{array}$} & \multicolumn{5}{|c|}{ Change Statistics } & \multirow[b]{2}{*}{$\begin{array}{l}\text { Durbin- } \\
\text { Watson }\end{array}$} \\
\hline & & & & & $\begin{array}{c}\text { R Square } \\
\text { Change }\end{array}$ & $\begin{array}{c}\mathrm{F} \\
\text { Change }\end{array}$ & df1 & $\mathrm{df} 2$ & $\begin{array}{l}\text { Sig. F } \\
\text { Change }\end{array}$ & \\
\hline 1 & $.858^{a}$ & .737 & .724 & 6.27932 & .737 & 59.480 & 4 & 85 & .000 & 1.314 \\
\hline
\end{tabular}

Jika angka D-W dibawah -2, berarti terdapat autokorelasi positif. Jika angka D-W diantara -2 sampai +2 , berarti tidak ada autokorelasi. Jika angka $\mathrm{D}-\mathrm{W}$ diatas +2 , berarti terdapat autokorelasi negatif. 
Berdasarkan tabel IV.15 diperoleh angka D-W sebesar 1.314. Hal ini menunjukkan bahwa model regresi pada penelitian ini bebas dari autokorelasi, karena angka D-W tersebut berada diantara angka -2 sampai +2 .

Pengujian hipotesis dalam penelitian ini dilakukan secara parsial. Pengujian variabel independen secara parsial dilakukan untuk mengetahui pengaruh masing-masing variabel independen (pengalaman, kesadaran etis, situasi audit, profesionalisme) terhadap variabel dependen (skeptisisme professional auditor). Dengan tingkat keyakinan 95\% dan dengan pengujian dua arah (two tail test), tingkat

signifikansi ditetapkan sebesar $5 \%$, dengan degree of freedom $(\mathrm{df})=\mathrm{n}-\mathrm{k}$.

Dengan membandingkan nilai thitung dengan tabel atau melihat $p$ value masingmasing variabel dilakukan untuk tujuan hipotesis secara parsial (uji t). Apabila nilai $t_{\text {hitung }}>$ dari $t_{\text {tabel }}$ atau $p$ value $<\alpha$ maka $\mathrm{H}_{\mathrm{a}}$ diterima dan $\mathrm{H}_{\mathrm{o}}$ ditolak, dengan kata lain variabel independen secara individual berpengaruh signifikan terhadap variabel dependen. Sebaliknya, apabila $t_{\text {hitung }}<$ dari tabel atau $p$ value $>\alpha$ maka $\mathrm{H}_{\mathrm{a}}$ ditolak dan $\mathrm{H}_{\mathrm{o}}$ diterima, dengan kata lain variabel independen secara individual tidak berpengaruh signifikan terhadap variabel dependen.

\section{Pengalaman $\left(\mathrm{X}_{1}\right)$}

Berdasarkan hasil perhitungan regresi pada Tabel diperoleh koefisien pengalaman sebesar 0.891 yang menunjukkan adanya pengaruh positif antara pengalaman terhadap skeptisisme professional auditor. Semakin lama pengalaman seorang auditor maka akan semakin tinggi skeptisisme professional oleh seorang auditor. Untuk mengetahui perbandingan signifikansi variabel pengalaman, hasil uji t diperoleh sebagai berikut :

$$
\begin{aligned}
& \mathrm{t}_{\text {hitung }}=2.270 \\
& \mathrm{t}_{\text {tabel }}=1.984 \\
& \mathrm{t}_{\text {hitung }}>\mathrm{t}_{\text {tabel }}, \mathbf{H}_{\mathbf{a}} \text { diterima, } \mathbf{H}_{\mathbf{o}} \text { ditolak }
\end{aligned}
$$

Pengambilan keputusan juga dapat dilakukan dengan melihat probabilitas variabel, dimana nilainya $0.026(p<0.05)$. Penelitian tersebut menunjukkan bahwa pengalaman mempunyai pengaruh yang signifikan terhadap skeptisisme professional auditor. Auditor yang berpengalaman memiliki tingkat selektifitas yang lebih tinggi terhadap informasi yang relevan, sehingga mempengaruhi seorang auditor untuk memiliki sikap skeptisisme professional auditor. Dengan demikian dapat disimpulkan bahwa hasil pengujian ini mendukung hipotesis pertama. Artinya pengalaman berpengaruh signifikan terhadap skeptisisme professional auditor.

\section{Kesadaran Etis $\left(\mathrm{X}_{2}\right)$}

Berdasarkan hasil perhitungan regresi pada Tabel diperoleh koefisien pengalaman sebesar 0.366 yang menunjukkan adanya pengaruh positif antara kesadaran etis terhadap skeptisisme professional auditor. Semakin tinggi tingkat 
kesadaran etis atau tidak etisnya tindakan yang diambil dalam pengambilan keputusan maka akan semakin meningkat skeptisisme professional auditor. Untuk mengetahui perbandingan signifikansi variabel kesadaran etis, hasil uji t diperoleh sebagai berikut :

$$
\begin{aligned}
& \mathrm{t}_{\text {hitung }}=2.636 \\
& \mathrm{t}_{\text {tabel }}=1.984 \\
& \mathrm{t}_{\text {hitung }}>\mathrm{t}_{\text {tabel }}, \mathbf{H}_{\mathbf{a}} \text { diterima, } \mathbf{H}_{\mathbf{o}} \text { ditolak }
\end{aligned}
$$

Pengambilan keputusan juga dapat dilakukan dengan melihat probabilitas variabel, dimana nilainya $0.010(p<0.05)$. Penelitian tersebut menyatakan bahwa faktor-faktor kecondongan etika berpengaruh terhadap skeptisisme professional auditor. Akuntan secara terus menerus akan berhadapan dengan dilemma etika yang melibatkan pilihan antara nilai-nilai yang bertentangan. Karena pertimbangan professional, maka sikap skeptisisme professional auditor sangat penting dalam memegang teguh prinsip-prinsip etika. Dengan demikian dapat disimpulkan bahwa hasil pengujian ini mendukung hipotesis kedua. Artinya kesadaran etis berpengaruh signifikan terhadap skeptisisme professional auditor.

\section{Situasi Audit $\left(\mathrm{X}_{3}\right)$}

Berdasarkan hasil perhitungan regresi pada Tabel diperoleh koefisien situasi audit sebesar 1.554 yang menunjukkan adanya pengaruh positif antara situasi audit terhadap skeptisisme professional auditor. Semakin besar tingkat resiko penemuan yang direncanakan dalam menghadapi suatu situasi audit maka akan semakin meningkat skeptisisme professional auditor. Untuk mengetahui perbandingan signifikansi variabel situasi audit, hasil uji t diperoleh sebagai berikut :

$$
\begin{aligned}
& t_{\text {hitung }}=6.281 \\
& t_{\text {tabel }}=1.984 \\
& t_{\text {hitung }}>t_{\text {tabel }}, \mathbf{H}_{\mathbf{a}} \text { diterima, } H_{o} \text { ditolak }
\end{aligned}
$$

Pengambilan keputusan juga dapat dilakukan dengan melihat probabilitas variabel, dimana nilainya $0.000(p<0.05)$. Penelitian tersebut menyatakan bahwa faktor situasi audit berpengaruh terhadap skeptisisme professional auditor. Dimana apabila dalam pelaksanaan auditnya seorang auditor yang lebih tinggi karena audit dirancang untuk memberikan keyakinan memadai atas pendeteksian salah saji material dalam laporan keuangan. Dengan demikian dapat disimpulkan bahwa hasil pengujian ini mendukung hipotesis ketiga. Artinya situasi audit berpengaruh signifikan terhadap skeptisisme professional auditor.

\section{Koefisien Determinasi}

Nilai koefisien determinasi $\left(\mathrm{R}^{2}\right)$ merupakan ukuran yang digunakan untuk menilai seberapa baik suatu model yang ditetapkan dapat menjelaskan variabel dependen. Apabila $\mathrm{R}^{2}$ bernilai 0 maka dapat dikatakan bahwa tidak ada variasi variabel dependen yang dapat dijelaskan oleh hubungan tersebut, dan jika $\mathrm{R}^{2}$ bernilai 1 maka dapat dikatakan bahwa semua variasi variabel dependen dapat 
dijelaskan. Dengan demikian $\mathrm{R}^{2}$ bernilai antara 0 dan 1 . Berikut adalah tabel hasil perhitungan $\mathrm{R}^{2}$ dengan menggunakan aplikasi SPSS.

Koefisien Determinasi

\begin{tabular}{|l|r|r|rr|}
\hline Model & R & R Square & \multicolumn{2}{|c|}{ Adjusted R Square } \\
\hline 1 & & $.858^{\mathrm{a}}$ & .737 & .724 \\
\hline
\end{tabular}

Berdasarkan tabel diatas diperoleh nilai $\mathrm{R}$ sebesar 0.858 dan $\mathrm{R}$ square $\left(\mathrm{R}^{2}\right)$ sebesar 0.737 atau $73.70 \%$. Koefisien determinasi atau $\mathrm{R}$ square $\left(\mathrm{R}^{2}\right)$ sebesar 0.737 memberi pengertian bahwa $73.70 \%$ skeptisisme professional auditor dipengaruhi oleh pengalaman, kesadaran etis, situasi audit sedangkan $26.30 \%$ dipengaruhi variabel lainnya. Dari persentase tersebut dapat dikatakan bahwa masih terdapat faktor individual lain sebesar $26.30 \%$ yang dapat dijelaskan oleh variabel lain yang dapat mempengaruhi skeptisisme professional auditor. Hal ini merupakan tantangan dan implikasi bagi peneliti lain untuk menjelaskan variabel tersebut.

\section{KESIMPULANDAN SARAN}

\section{Kesimpulan}

1. Secara umum hasil pengujian validitas dan reliabilitas untuk seluruh butir pertanyaan penelitian telah memberikan hasil yang baik dan patut dipertimbangkan untuk penelitian selanjutnya. Pengujian validitas terhadap seluruh butir pertanyaan dengan menggunakan korelasi pearson menunjukkan bahwa setiap butir pertanyaan memiliki tingkat validitas dan reliabilitas yang sesuai dengan korelasi pearson yaitu mendekati angka +1 .

2. Normalitas rata-rata jawaban responden yang menjadi data dalam penelitian ini dilihat dari normal probability plot menunjukkan bahwa distribusi jawaban responden adalah normal, sehingga persyaratan normalitas data terpenuhi.

3. Hasil pengujian hipotesis pertama menunjukkan bahwa variabel pengalaman berpengaruh signifikan terhadap skeptisisme professional auditor. Penelitian ini menunjukkan bahwa pengalaman mempunyai pengaruh yang signifikan terhadap skeptisisme professional auditor. Dengan demikian dapat disimpulkan bahwa hasil pengujian ini mendukung hipotesis pertama. Artinya pengalaman berpengaruh signifikan terhadap skeptisisme professional auditor.

4. Hasil pengujian hipotesis kedua menunjukkan bahwa variabel kesadaran etis berpengaruh signifikan terhadap skeptisisme professional auditor. Penelitian ini menyatakan bahwa faktor-faktor kecondongan etika berpengaruh terhadap skeptisisme professional auditor. Dengan demikian dapat disimpulkan bahwa hasil pengujian ini mendukung hipotesis kedua. Artinya kesadaran etis berpengaruh signifikan terhadap skeptisisme professional auditor. 
5. Hasil pengujian hipotesis ketiga menunjukkan bahwa variabel situasi audit berpengaruh signifikan terhadap skeptisisme professional auditor. Penelitian ini menyatakan bahwa faktor situasi audit berpengaruh terhadap skeptisisme professional auditor. Dengan demikian dapat disimpulkan bahwa hasil pengujian ini mendukung hipotesis ketiga. Artinya situasi audit berpengaruh signifikan terhadap skeptisisme professional auditor.

6. Hasil pengujian koefisien determinasi $\left(\mathrm{R}^{2}\right)$ sebesar 0.737 memberi pengertian bahwa $73.70 \%$ skeptisisme professional auditor dipengaruhi oleh pengalaman, kesadaran etis, situasi audit. Meskipun penelitian ini hanya menguji secara parsial, tetapi dari jumlah koefisien determinasi sebesar $73.70 \%$ member gambaran bahwa masih ada $26.30 \%$ variabel lain yang mempengaruhi skeptisisme professional auditor.

\section{Saran}

1. Auditor dalam melaksanakan audit harus memperhatikan faktor-faktor yang akan mempengaruhi pengumpulan bukti audit yang dilakukan. Dalam pengumpulan bukti audit, auditor dituntut untuk memiliki skeptisisme professional yang tinggi, karena pada akhirnya akan mempengaruhi opini yang diberikannya.

2. Peneliti selanjutnya dapat memperluas area survey tidak hanya di Sumatera tetapi seluruh wilayah Indonesia. Hal ini akan dapat lebih mewakili seluruh populasi auditor.

3. Peneliti selanjutnya dapat menambahkan variabel penelitian lainnya yang diduga mempengaruhi skeptisisme professional auditor.

4. Peneliti selanjutnya disarankan melakukan kerjasama dengan peneliti lainnya yang memiliki populasi yang sama. Dalam hal ini, peneliti berikutnya bekerjasama dalam hal penyebaran kuesioner serta penjangkauan responden yang terpisah, sehingga tingkat pengembalian kuesioner akan lebih besar. 


\section{DAFTAR PUSTAKA}

Agoes Soekrisno. 2004. Auditing 2 Pemeriksaan Akuntansi Oleh Akuntan Publik, Edisi Ketiga. Jakarta : LPFE-UI.

Agoes Soekrisno. 2009. Etika Bisnis dan Profesi. Jakarta : LPFE-UI.

Maghfirah dan Syahril. 2008. Hubungan Skeptisisme Profesional Auditor dan Situasi Audit, Etika, Pengalaman serta Keahlian Audit dengan Ketepatan Pemberian Opini Auditor oleh Akuntan Publik. Simposium Nasional Akuntansi XI. Pontianak.

Mulyadi. 2002. Auditing. Edisi Keenam. Jakarta: Salemba Empat.

Shaub, K. Michael dan Jenice E. Lawrence. 1996. Ethics Experience and Professional Scepticism: A Situational Analysis. Behavioral Research In Accounting Vol 8, 124-157.

Soekrisno, A., 2004. Auditing: Pemeriksaan Akuntansi Oleh Akuntan Publik, Ed. Ke-3. LPFE-UI, Jakarta.

Soekrisno, A., 2009. Etika Bisnis dan Profesi. LPFE-UI, Jakarta.

Wahyudi Hendro. 2006. Pengaruh Profesionalisme Auditor Terhadap Tingkat Materialisme Dalam Pemeriksaan Laporan Keuangan. SNA IX, STIE Malangkucecwara, Malang.

Yurniwati dan Eka D.P. 2004. Hubungan Pengalaman dan Situasi Audit dengan Skeptisisme Profesional Auditor. Laporan Penelitian. Fakultas Ekonomi Universitas Andalas.

Yurniwati dan Indah K. 2004. Hubungan Kesadaran Etis dan Keahlian dengan Skeptisisme Profesional Auditor. Laporan Penelitian. Fakultas Ekonomi Universitas Andalas. 